\title{
Hitung Leukosit pada Inflamasi Kaki Mencit (Mus musculus) Induksi Karagenan dengan Sarang Walet Putih (Collocali fuciphaga)
}

\section{Leukocyt on Carragenaan-Induced Inflammation by Edible Bird's Nest (EBN) (Collocalia fuchipagha)}

Fitri Nuroini ${ }^{1 *}$ dan Zulfikar Husni Faruq ${ }^{2}$

${ }^{1}$ Laboratorium Patologi Klinik, Fakultas Ilmu Keperawatan dan Kesehatan, Universitas Muhammadiyah Semarang ${ }^{2}$ Laboratorium Hematologi, Fakultas Ilmu Keperawatan dan Kesehatan, Universitas Muhammadiyah Semarang *Corresponding author: fitrinuroini@unimus.ac.id

\begin{abstract}
ABSTRAK
Inflamasi merupakan respon protektif setempat yang diperlukan tubuh untuk mempertahankan diri dari berbagai bahaya sekaligus memperbaiki kerusakan struktur dan gangguan fungsi jaringan yang ditimbulkan oleh bahaya tersebut (Baratawidjaja, 2002). Sel-sel yang berperan dalam inflamasi yaitu eritrosit, neutrofil, basofil, eosinofil, platelet, sel NK (natural killer), limfosit, sel mast, sel dendritik dan antigen presenting cells (Liao dkk, 2011). Apabila penyebab inflamasi tidak dapat disingkirkan, akan terjadi inflamasi kronikyang dapat merusakjaringan dan kehilangan fungsi sama sekali (Baratawidjaja, 2002). Oleh karena itu, inflamasi berlanjut perlu dicegah salah satunya dengan mengkonsumsi obat alternatif salah satunya adalah sarang walet putih (Collocalia fuciphaga). Tujuan penelitian ini adalah untuk mengetahui potensi EBN burung walet sarang putih (C. fuchipaga) terhadap profil darah mencit (leukosit total dan leukosit deferensial) pada jam kelima setelah diinduksi karagenan. Penelitian ini menggunakan Rancangan Acak Lengkap dengan 6 kelompok perlakuan, masing-masing 4 ulangan. Kelompok perlakuan terdiri atas kontrol normal, kontrol negatif, kontrol positif dan perlakuan pemberian ekstrak akuosa EBN dengan dosis 0,1; 1 dan 10 mg/20 $g$ BB. Semua perlakuan diberikan secara peroral kemudian setelah satu jam tiap kelompok diinjeksi 0,05 ml karagenan 1\% dalam $\mathrm{NaCl}$ 0,9\% pada telapak kaki kanan mencit secara subkutan. Hasil penelitian menunjukkan bahwa pemberian EBN secara oral dapat dapat menurunkan secara signifikan $(p<0,05)$ jumlah leukosit total dan leukosit deferensial terutama limfosit dan neutrofil.
\end{abstract}

Kata kunci: Leukosit, Inflamasi, Karagenan, Sarang Walet Putih, EBN

\begin{abstract}
Inflammation is a local protective response that needed to body defend from various hazards and also repairing/recovery (Baratawidjaja, 2002). Erythrocytes, neutrophils, basophils, eosinophils, platelets, NK cells (natural killers), lymphocytes, mast cells, dendritic cells and antigen presenting cells are cells that play a role in inflammation (Liao et al, 2011). If inflammation cannot be eliminated, chronic inflammation will occur which can damage the tissue and lose function (Baratawidjaja, 2002). Therefore, continued inflammation needs to be prevented by consuming alternative medicine one of them is Swiftlets Collocalia fuciphaga or EBN. The aims of this study was to determine the anti-inflammatory effect of EBN swiftlet C. fuciphaga in total leukocyte count and leukocyte differential count. Research design using Randomized Complete Design (RCD) with 6 treatment and 4 replication. The treatment are normal control group, negative control group, positive control group and 3 group treatment with EBN extract $(0.1,1 \mathrm{and} 10 \mathrm{mg} / 20 \mathrm{~g} \mathrm{~W}$. EBN was given orally and after an hour each group were injected subcutaneously with $0.05 \mathrm{ml}$ of $1 \%$ carrageenan in 0.9 $\% \mathrm{NaCl}$ on the right foot mice. The results showed that administration of oral EBN inhibit carrageenan-induced inflammation. Administration EBN orally was significantly decresed $(p<0.05)$ total leukocyte count and leukocyte differential count, mainly neutrophils and lymphocytes.
\end{abstract}

Keyword: Leukocyt, Inflammation, Carrageenan, Swiftlets Nest, EBN

\section{PENDAHULUAN}

Inflamasi merupakan respon protektif setempat yang diperlukan tubuh untuk mempertahankan diri dari berbagai bahaya yang dapat mengganggu keseimbangan dan sekaligus memperbaiki kerusakan struktur dan gangguan fungsi jaringan yang ditimbulkan oleh bahaya tersebut (Baratawidjaja, 2002). Reaksi vaskuler terjadi pada reaksi inflamasi sehingga cairan, elemen darah, leukosit dan mediator kimia 
menuju daerah inflamasi untuk menetralkan dan menghilangkan agen-agen berbahaya serta memperbaiki jaringan yang rusak. Mediator kimia tersebut berasal dari jaringan yang rusak, sel mast, leukosit dan komplemen yang dilepaskan atau diaktifkan pada lokasi inflamasi untuk kemudian diinaktifkan (Baratawidjaja, 2002; Tanu dkk, 2002; Kee dan Hayes dalam Hidayati dkk, 2008; Wilmana dalam Hidayati dkk, 2008). Sel-sel yang berperan dalam inflamasi yaitu eritrosit, neutrofil, basofil, eosinofil, platelet, sel NK (natural killer), limfosit, sel mast, sel dendritik dan antigen presenting cells (Liao dkk, 2011).

Tanda inflamasi akut adalah kemerahan (dolor), pembengkakan atau edema (tumor), panas (kalor), nyeri (rubor) dan perubahan atau hilangnya fungsi (function laesa) (Baratawidjaja, 2002; Tanu dkk, 2002; Price dan Wilson dalam Rustam dkk, 2007; Mycek dkk dalam Sutrisna dkk, 2010). Proses inflamasi akan berjalan sampai antigen dapat disingkirkan. Inflamasi akan pulih setelah mediator kimia diinaktifkan. Apabila penyebab inflamasi tidak dapat disingkirkan atau terjadi pajanan berulang dengan antigen, akan terjadi inflamasi kronik yang dapat merusak jaringan dan kehilangan fungsi sama sekali (Baratawidjaja, 2002). Oleh karena itu, meskipun inflamasi merupakan respon alami tubuh, inflamasi berlanjut perlu dicegah salah satunya dengan mengkonsumsi obat. Akan tetapi, konsumsi obat sering diikuti dengan efek samping apabila konsumsi dilakukan dalam jangka panjang atau berlebihan. Obat alternatif dari bahan alam cenderung tanpa atau sedikit memberikan efek samping sehingga perlu dikembangkan salah satunya adalah sarang walet putih (Collocalia fuciphaga).

Sarang walet putih disebut dengan EBN (Edible Bird's Nest) karena sarang walet dapat dimakan/dikonsumsi. EBN berasal dari air liur yang diproduksi oleh sepasang kelenjar saliva sub lingualis yang mengeras, berwarna putih dan memiliki bentuk seperti cawan (Goh dkk,
2001; Soehartono dan Mardiastuti, 2003). Komposisi utama sarang walet putih adalah karbohidrat dan glikoprotein (Kathan dan Weeks, 1969). Menurut Marcone (2005) komposisi EBN dari Genus Collocalia Indonesia dan Malaysia terdiri atas karbohidrat $(25,62-27,26 \%)$, protein $(62-63 \%)$, lipid $(0,14-1,28 \%)$ dan abu $(2,1 \%)$. Manfaat EBN sangat banyak dan telah diketahui sejak abad ke 17 oleh bangsa Cina sebagai obat tradisional (RamLi dan Azmi, 2012). Komponen glikoprotein yang terdapat pada EBN dapat meningkatkan proliferasi makrofag dan menghambat produksi TNF- $\alpha$ sebagai faktor proinflamasi pada kultur sel RAW 264.7 dari leukosit tikus leukimia (Aswir dan Wan Nazaimoon, 2011). Penelitian ini merupakan lanjutan dari penelitian sebelumnya yang dilakukan oleh Nuroini (2017). Tujuan penelitian ini adalah untuk mengetahui potensi EBN burung walet sarang putih (C. fuchipaga) terhadap profil darah mencit (leukosit total dan leukosit deferensial) pada jam kelima setelah diinduksi karagenan.

\section{METODE PENELITIAN}

Alat dan bahan yang digunakan antara lain sarang walet putih (Collocalia fuciphaga) atau EBN, karagenan lambda, larutan Turk, methanol, dan Giemsa, kandang mencit, Haemocytometer, object glass, cover glass, dan mikroskop. Hewan uji menggunakan mencit jantan (Mus musculus) galur Swiss sebanyak 24 ekor umur 8 minggu dengan berat badan berkisar 2226 g. Penelitian dilakukan di laboratorium Hematologi Analis Kesehatan Universitas Muhammadiyah Semarang pada bulan Mei-Juli 2018.

\section{Rancangan Penelitian dan Induksi Karagenan}

Rancangan percobaan yang digunakan adalah Rancangan Acak Lengkap (RAL) dengan 6 kelompok perlakuan yaitu kontrol normal, kontrol positif, kontrol negatif, perlakuan 
cekok EBN 0,1; 1 dan 10 mg/ 20 g BB, masingmasing kelompok dengan 4 ulangan. Penelitian dilaksanakan dengan melakukan uji aktivitas inflamasi berdasarkan pada metode Winter yang sudah dimodifikasi (Turner, 1965). Uji aktivitas inflamasi tersebut berupa edema buatan yang ditimbulkan dengan menginjeksikan karagenan 1\% yang dilarutkan dalam larutan $\mathrm{NaCl} 0,9 \%$, sebanyak $0,05 \mathrm{~mL}$ pada bagian dorsal kaki kanan mencit secara subkutan (Xu dkk, 2012). Injeksi karagenan dilakukan 1 jam setelah pemberian perlakuan EBN per oral.

\section{Pembuatan Ekstrak Akuosa EBN Walet Collocalia fuciphaga}

Sarang walet (EBN) C. fuciphaga dikeringkan terlebih dahulu dalam oven pada suhu $60^{\circ} \mathrm{C}$ selama \pm 5 hari kemudian dihaluskan dengan mortar dan alu. Sampel EBN yang sudah dihaluskan dengan sempurna diletakkan dalam wadah yang kedap udara dan disimpan pada suhu ruangan sampai analisis selanjutnya (Norhayati dkk, 2010; Vimala dkk, 2012).

\section{Aklimasi Hewan Uji}

Mencit yang digunakan dalam penelitian sebanyak 24 ekor, dibagi dalam 6 kelompok, 3 kelompok kontrol dan 3 kelompok perlakuan. Mencit diaklimasi selama 1 minggu dalam ruangan penelitian dengan diberikan pakan standar berupa pelet dan minum secara ad libitum.

\section{Uji Efek Antiinflamasi}

Mencit dipuasakan selama \pm 24 jam sebelum dilakukan pengujian, air minum tetap diberikan secara ad libitum. Mencit pada masing-masing kelompok diberikan perlakuan sesuai dengan rancangan kelompok penelitian. Kelompok I sebagai kontrol normal tidak diberi perlakuan apapun termasuk induksi karagenan. Kelompok II sebagai kontrol negatif dengan pemberian akuades sebanyak 0,5 mL/ 20 g BB. Kelompok
III sebagai kontrol positif dengan pemberian Na-diklofenak sebanyak 2,5 mg/ $20 \mathrm{~g} \mathrm{BB}$. Kelompok IV, V dan VI dengan pemberian bahan uji berupa ekstrak akuosa EBN dengan dosis berturut-turut $0,1,1 \mathrm{dan} 10 \mathrm{mg} / 20 \mathrm{~g} \mathrm{BB}$. Semua perlakuan pada kelompok II-VI diberikan secara per oral dengan menggunakan spuit injek per oral (jarum kanul) $1 \mathrm{~mL}$ dengan volume $0,5 \mathrm{~mL} / 20 \mathrm{~g}$ BB. Satu jam kemudian tikus pada kelompok II-VI diinjeksi karagenan $1 \%$ yang dilarutkan dalam larutan $\mathrm{NaCl} 0,9 \%$, sebanyak $0,05 \mathrm{~mL}$ pada telapak kaki kanan mencit secara subkutan (Xu dkk, 2012). Darah diambil pada jam ke-5 dari sinus orbitalis menggunakan tabung mikrohematokrit kemudian dilakukan penghitungan jumlah leukosit total dan leukosit diferensial (Sari, 2008).

\section{Perhitungan Jumlah Leukosit Total}

Perhitungan jumlah leukosit total dilakukan menggunkan haemocytometer dengan pengenceran 1:20. Sampel darah yang telah diberi anti koagulan (EDTA) dihisap menggunakan pipet thoma leukosit sampai angka 0,1 kemudian dilanjutkan dengan larutan Turk dihisap sampai angka 11. Pipet digoyang supaya darah dan larutan pengencer bercampur homogen. Duatiga tetes campuran pertama dibuang kemudian tetes-tetes berikutnya digunakan untuk penghitungan. Bilik hitung dan gelas penutup dipasang pada mikroskop, kemudian dicari bilik hitung leukosit, hingga bujur sangkar terlihat jelas. Ujung pipet ditempelkan pada tepi gelas penutup sehingga bujur sangkar terisi penuh. Jumlah leukosit yang terdapat pada 4 bujur sangkar luar (L) dihitung. Jumlah leukosit setiap $\mathrm{mm}^{3}$ adalah jumlah sel terhitung dikalikan dengan 25 (Tambur, 2006). Jumlah leukosit total dihitung menggunakan rumus=

$$
\text { Jumlah leukosit/ } \mathrm{mm}^{3}=\frac{\mathrm{L}}{64} \times 160 \times 10=25
$$

\section{Penghitungan Leukosit Diferensial}

Penghitungan leukosit diferensial dilakukan dengan membuat preparat apus darah. 
Pembuatan preparat apus darah dimulai dengan meneteskan sampel darah pada ujung gelas benda. Kemudian dengan menggunakan ujung gelas benda yang lain, disentuhkan pada tetesan darah tersebut dan gelas benda digeser atau ditarik dengan sudut $45^{\circ}$. Sediaan dibiarkan beberapa saat hingga mengering kemudian difiksasi selama 5 menit dengan metanol. Pemulas Giemsa diteteskan di atas sediaan hingga apusan tertutup seluruhnya oleh pemulas, dibiarkan selama 30 menit. Sediaan dicuci dengan akuades dan dibiarkan mengering dalam suhu ruangan. Penghitungan jumlah leukosit diferensial dilakukan hingga jumlah total leukosit mencapai 100 sel. Masingmasing jenis leukosit dihitung persentasenya dari 100 leukosit yang ditemukan pada setiap sediaan (Fox, 1990).

\section{Analisis Data}

Data tebal integumentum dianalisis dengan ANOVA dan dilanjutkan dengan uji Duncan's Multiple Range Test (DMRT) pada taraf signifikansi 95\%.

\section{HASIL DAN PEMBAHASAN}

Inflamasi akut ditandai dengan adanya pembengkakan atau edema (tumor), panas (kalor), kemerahan (dolor), nyeri (rubor) dan perubahan atau hilangnya fungsi (function laesa) (Baratawidjaja, 2002; Tanu dkk, 2002; Price dan Wilson dalam Rustam dkk, 2007; Mycek dkk dalam Sutrisna dkk, 2010). Radang atau edema buatan merupakan salah satu cara untuk uji aktivitas inflamasi dengan injeksi karagenan 1\% dalam larutan $\mathrm{NaCl} 0,9 \% \quad(\mathrm{Xu}$ dkk, 2012). Karagenan merupakan senyawa iritan sebagai induktor radang dengan menyebabkan cedera sel melalui pelepaskan mediator sebagai proses awal terjadinya inflamasi. Radang buatan dengan injeksi karagenan akan terjadi selama 6 jam dengan puncak radang maksimal pada jam ketiga dan kelima dan secara berangsur akan berkurang dalam waktu
24 jam (Ravi dkk, 2009).

Leukosit meliputi neutrofil, limfosit, basofil, eosinofil dan monosit (selanjutnya berdeferensiasi menjadi makrofag) merupakan salah satu sel yang berperan dalam melawan antigen pencetus inflamasi. Reaksi vaskuler yang terjadi selama proses inflamasi memungkinkan elemen-elemen darah, leukosit dan mediator kimia menuju daerah inflamasi. Hasil perhitungan jumlah leukosit total darah mencit setelah induksi karagenan tercantum pada Tabel 1.

Pemberian EBN secara oral berpengaruh nyata terhadap jumlah leukosit pada reaksi inflamasi yang diinduksi karagenan. Terdapat variasi jumlah leukosit pada masing-masing kelompok perlakuan akan tetapi masih dalam kisaran normal. Menurut Fox dkk (2007) kisaran normal jumlah leukosit total pada mencit antara 2.000 sampai $10.000 / \mu \mathrm{L}$. Pemberian EBN secara oral dapat menurunkan jumlah leukosit total darah mencit pada reaksi inflamasi yang diinduksi karagenan. Penurunan jumlah leukosit tampak pada masing-masing kelompok perlakuan pemberian EBN secara oral, penurunan tertinggi terjadi pada kelompok perlakuan cekok EBN $1 \mathrm{mg} / 20 \mathrm{~g}$ BB. Penurunan tersebut telah mendekati jumlah leukosit total pada kelompok kontrol normal, sehingga pemberian EBN pada mencit inflamasi yang diinduksi karagenan telah kembali pada kondisi normal. Penurunan leukosit dalam darah terjadi karena adanya suplai leukosit yang besar pada daerah yang mengalami inflamasi. Anosike dkk (2009) dan Hariot dkk (2004) melaporkan bahwa puncak inflamasi dengan induksi karagenan terjadi pada 3-5 jam setelah injeksi karagenan. Berdasarkan penelitian Nuroini (2013) terhadap mencit inflamasi yang diinduksi karagenan terjadi penurunan leukosit pada kelompok perlakuan pemberian EBN secara oral pada pengukuran jumlah leukosit total 4 jam setelah penyuntikan karagenan. Penelitian ini menunjukkan hal yang sama bahwa pada 5 jam setelah penyuntikan karagenan juga terjadi penurunan 
Tabel 1. Jumlah Leukosit Total Darah Mencit setelah Induksi Karagenan

\begin{tabular}{lc}
\multicolumn{1}{r}{ Kelompok Perlakuan } & Leukosit Total $\left(\mathbf{m m}^{3}\right)$ \\
\hline Kontrol Normal & $5250 \pm 2,65^{\mathrm{a}}$ \\
Kontrol Positif & $5950 \pm 6,80^{\mathrm{b}}$ \\
Kontrol Negatif & $7850 \pm 1,78^{\mathrm{c}}$ \\
P1 & $5900 \pm 2,05^{\mathrm{ab}}$ \\
P2 & $4050 \pm 8,98^{\mathrm{a}}$ \\
P3 & $4250 \pm 6,72^{\mathrm{a}}$ \\
\hline
\end{tabular}

Data ditampilkan dalam nilai rata-rata \pm standar error. Huruf yang berbeda pada setiap nilai di kolom yang sama menunjukkan perbedaan yang nyata $(\mathrm{P}<0,05)$.

Keterangan: Kontrol normal: akuades; kontrol positif: karagenan + natrium diklofenak; kontrol negatif: karagenan; $\mathrm{P} 1$ : karagenan + EBN 0,1 mg/20 g BB; P2: karagenan + EBN 1 mg/20 g BB; P3: karagenan + EBN 10 mg/20 g BB.

Tabel 2. Jumlah Leukosit Deferensial Darah Mencit Setelah Induksi Karagenan

\begin{tabular}{|c|c|c|c|c|c|}
\hline \multirow{2}{*}{$\begin{array}{l}\text { Kelompok } \\
\text { Perlakuan }\end{array}$} & \multicolumn{5}{|c|}{ Leukosit Deferensial (\%) } \\
\hline & Basofil & Eosinofil & Limfosit & Monosit & Neutrofil \\
\hline Kontrol & $0,05 \pm 0,05^{\mathrm{a}}$ & $0,25 \pm 0,00^{\mathrm{a}}$ & $64,50 \pm 3,50^{\mathrm{b}}$ & $3,50 \pm 3,50^{\mathrm{a}}$ & $24,00 \pm 2,00^{\mathrm{a}}$ \\
\hline $\begin{array}{l}\text { Kontrol } \\
\text { Positif } \\
\text { Kontrol }\end{array}$ & $0,00 \pm 0,00^{\mathrm{a}}$ & $2,00 \pm 0,00^{\mathrm{a}}$ & $76,50 \pm 2,50^{\mathrm{c}}$ & $3,50 \pm 0,00^{\mathrm{a}}$ & $36,50 \pm 4,50^{b}$ \\
\hline Negatif & $0,25 \pm 0,25^{\mathrm{a}}$ & $1,00 \pm 0,50^{\mathrm{a}}$ & $58,00 \pm 3.00^{\mathrm{a}}$ & $2,00 \pm 0,00^{\mathrm{a}}$ & $47,50 \pm 1,50^{\mathrm{c}}$ \\
\hline P1 & $0,00 \pm 0,00^{\mathrm{a}}$ & $1,00 \pm 0,00^{\mathrm{a}}$ & $61,50 \pm 7.50^{\mathrm{b}}$ & $2,50 \pm 1,50^{\mathrm{a}}$ & $37,50 \pm 2,50^{\mathrm{ab}}$ \\
\hline P2 & $0,00 \pm 0,00^{\mathrm{a}}$ & $1,00 \pm 0,00^{\mathrm{a}}$ & $64,00 \pm 1.50^{\mathrm{b}}$ & $3,00 \pm 1,00^{\mathrm{a}}$ & $36,00 \pm 0,00^{\mathrm{ab}}$ \\
\hline P3 & $0,25 \pm 0,50^{\mathrm{a}}$ & $1,00 \pm 0,00^{\mathrm{a}}$ & $62,00 \pm 6.00^{\mathrm{b}}$ & $3,50 \pm 0,00^{\mathrm{a}}$ & $19,50 \pm 6,00^{\mathrm{a}}$ \\
\hline
\end{tabular}

Data ditampilkan dalam nilai rata-rata \pm standar error. Huruf yang berbeda pada setiap nilai di kolom yang sama menunjukkan perbedaan yang nyata $(\mathrm{P}<0,05)$.

Keterangan:Kontrol normal: akuades; kontrol positif: karagenan + natrium diklofenak; kontrol negatif: karagenan; P1: karagenan + EBN 0,1 mg/20 g BB; P2: karagenan + EBN 1 mg/20 g BB; P3: karagenan + EBN 10 mg/20 g BB.

kadar leukosit total.

Hasil hitung jumlah leukosit deferensial pada Tabel 2. diketahui bahwa jumlah sel basofil, eosinofil dan monosit pada masing-masing kelompok kontrol dan kelompok perlakuan pada penelitian ini tidak terdapat perbedaan yang signifikan. Jumlah sel basofil, eosinofil dan monosit yang ditemukan pada tiap-tiap kelompok perlakuan masih dalam kisaran normal mencit yaitu secara berturut-turut $0-0,8$ $\%, 0,2-3,5 \%$ dan 0,8-3,8 \% (Giknis dan Clifford, 2008). Basofil memiliki heparin yang akan dilepaskan pada daerah inflamasi untuk mencegah pembekuan, statis darah dan limfe, sehingga diduga sebagai prekursor bagi sel mast (Frandson, 1992). Sedangkan eosinofil penting dalam respon terhadap penyakit parasitik dan alergi (Hoffbrand, 2006). Menurut Baratawidjaja (2002) monosit akan bermigrasi dari sistem sirkulasi darah menuju daerah inflamasi dan berdeferensiasi menjadi makrofag, fungsi utama makarofag adalah untuk fagositosis.

Jumlah limfosit pada masing-masing kelompok perlakuan cekok EBN tidak berbeda secara signifikan dan mendekati jumlah limfosit kelompok kontrol normal, akan tetapi jumlah limfosit tersebut berbeda signifikan dengan kelompok kontrol positif dan negatif. Menurut Giknis dan Clifford (2008) kisaran normal jumlah sel limfosit pada mencit antara 66,6$90,3 \%$, pada penelitian ini jumlah sel limfosit semua kelompok perlakuan berada di bawah kisaran normal. Hal tersebut menunjukkan bahwa pemberian EBN secara oral memberikan pengaruh terhadap jumlah limfosit darah mencit yang mengalami inflamasi dengan diinduksi karagean. Pemberian EBN berpengaruh dengan menurunkan jumlah limfosit mencit yang mengalami inflamasi. Penurunan jumlah sel limfosit diduga karena terjadi akumulasi limfosit dalam jumlah besar ke daerah inflamasi. Fungsi utama limfosit adalah menanggapi 
kehadiran benda asing dengan membentuk antibodi yang diangkut dalam darah atau sistem kekebalan seluler (Frandson, 1992).

Jumlah limfosit pada masing-masing kelompok perlakuan berbeda nyata dengan kelompok kontrol negatif, akan tetapi tidak berbeda nyata dengan keompok kontrol normal dan kontrol positif. Berdasarkan hal tersebut dapat diketahui bahwa pemberian EBN secara oral memberikan pengaruh terhadap penurunan jumlah neutrofil mencit yang mengalami inflamasi dengan induksi karagenan. Kisaran normal sel neutrofil antara 6,2-26,7 \% (Giknis dan Clifford, 2008). Salah satu sel fagositik yang paling awal masuk ke dalam situs infeksi dan merupakan tanda klasik pada respon inflamasi adalah neutrofil. Neutrofil akan bermigrasi ke daerah inflamasi apabila kebutuhan neutrofil belum tercukupi sehingga akan menyebabkan terjadinya penurunan jumlah neutrofil (Fox dkk, 2007).

\section{KESIMPULAN}

Ekstrak EBN burung walet sarang putih $(C$. fuchipaga) berpengaruh terhadap jumlah leukosit total dan leukosit deferensial pada jam kelima setelah induksi karagenan.

\section{UCAPAN TERIMAKASIH}

Terimakasih kepada Kementrian Riset, Teknologi dan Pendidikan Tinggi atas hibah PDP sebagai sumber pendanaan pada penelitian ini.

\section{DAFTAR PUSTAKA}

Anosike, C.A., Obidoa, O., Ezeanyika, L.U.S. dan Nwuba M.M.. 2009. Anti-inflammatory and Anti-ulcerogenic Activity of The Ethanol Extract of Ginger (Zingiber officinale). African Journal of Biochemistry Research. 3(12):379-384.

Aswir, A.R, dan Wan Nazaimoon, W.M. 2011. Effect of Edible Bird's Nest on Cell Proliferation and Tumor Necrosis Factor-alpha (TNF- $\alpha$ ) Release in Vitro. International Food Research Journal. 18(3): 1123-1127.

Baratawidjaja, K.G. 2002. Imunologi Dasar. Edisi Kelima. Balai Penerbit Fakultas Kedokteran Universitas Indonesia. Jakarta.
Fox, S.I. 1990. A Labolatory Guide to Human Physiology (Concept Clinical Applications). $4^{\text {th }}$ ed. Macmilan. New York.

Fox, J.G., Barthold, S.W., Davisson, M.T., Newcomer, C.E., Quimbi, F.E. dan Smith, A.L. 2007. The Mouse in Biomedical Research: Normative Biology, Husbandry, and Models. $2^{\text {nd }} \mathrm{ed}$. Elsevier Inc. California.

Giknis, M.L.A. dan Clifford, C.B. 2008. Clinical laboratory parameters for Crl: Wl(Han). Charles Rivers Laboratory.

Goh, D.L.M., Chua, K.Y., Chew, F.T., Seow, T.K., Ou, K.L., Yi, F.C. dan Lee B.W. 2001. Immunochemical Characterisation of Edible Bird's Nest Allergens. J Allergy Clinical Immunol. 107 (6): 1082-1088.

Hoffbrand, V. 2006. At a Glance Hematology. EMS: Jakarta

Kathan, R.H., dan Weeks, D.I. 1969. Structure Studies of Collocalia Mucoid. I. Carbohydrate and Amino Acid Composition. Archives in Biochemistry and Biophysics. 134(2): 572-576

Krishnamoorthy, S. dan Honn, K.V. 2006. Inflammation ang Disease Progression. Cancer Metastasis Rev. 25: 481-491.

Marcone, M.F. 2005. Characterization of the Edible Bird's Nest the "Caviar of the East". Food Research International. 38: $1125-1134$.

Noorhayati, M.K., Azman, O. dan Wan Nazaimoon, W.M. 2010. Preliminari Study of the Nutritional Content of Malaysian Edible Bird's Nest. Mal JNutr. 16(3): 389-396.

Nuroini, F. 2013. Penghambatan Tumor Necrosis Factor-Alpha (TNF- $\alpha$ ) oleh Ekstrak Akuosa Sarang Burung Walet (Collocalia fuciphaga Thunberg) pada Respon Inflamasi Induksi Karagenan. Tesis. Universitas Gadjah Mada.

Nuroini, F, dan Wijayanti, N. 2017. Uji Efek Antiinflamasi Sarang Burung Walet (Collocalia fuciphaga Thunberg) terhadap Gambaran Histologis Telapak Kaki Mencit (Mus musculus Linneaus). Jurnal Labora Medika. 1(1):21-26.

Ravi, V., Saleem, T.S.M., Patel, S.S., Raamamurthy, J. dan Gauthaman, K. 2009. Anti-inflammatory Effect of Methanolic Extract of Solanum nigrum Linn. Berries. Inter. J. App. Res. Nat. Prod. 2 (2):33-36.

Rustam, E. Atmasari, I. dan Yanwirasti. 2007. Efek Antiinflamasi Ekstrak Etanol Kunyit (Curcuma domestika Val.) pada Tikus Putih Jantan Galur Wistar. Jurnal Sains dan Teknologi Farmasi. 12 (2): 112-115.

Soehartono, T. dan Mardiastuti, A. 2003. Pelaksanaan Konvensi CITES di Indonesia. Japan International Cooperation Agency(JICA). Jakarta.

Sutrisna, E.M., Widyasari, D.F. dan Suprapto. 2010. Uji Efek Antiinflamasi Ekstrak Etil Asetat Buah Semu Jambu Mete (Anacardium occidentale L.) terhadap Edema pada Telapak Kaki Tikus Putih (Rattus norvegicus) Jantan Galur Wistar yang Diinduksi Karagenan. Biomedika. 2(1):33-38.

Tambur, Z. 2006. White Blood Cell Differential Count in Rabbits Artificially Infected with Intestinal Coccidia. $J$. Protozool. Res 16, 42-50.

Turner, R.A. 1965. Screening Method in Pharmacolog. Academic Press. New York, USA.

Vimala, B., Hussain, H. dan Wan Nazaimoon, W.M. 2012. Effect of Edible Bird's Nest on Tumoiability of Lipopolysaccharide-stimulated RAW 264.7 Macrophage. Food and Agricultural Immunology. 23 (4): 303-314.

Xu, Z., Zhou, J., Cai, J., Zhu, Z., Sun, X., dan Jiang, C. 2012. Anti-inflammatory Effects of Hydrogen Saline in LPS Activated Macrophages and Carrageenan Anduced Paw Oedema. Journal of Inflammation. 9 (2): 1-8. 